\title{
Al-Qawāid Al-Fiqhiyyah Terhadap Perbedaan Pendapat Dalam Fiqih (Kasus Hukuman Tindak Pidana Korupsi)
}

\author{
Teguh Luhuringbudi ${ }^{* 1)}$; Achmad Yani ${ }^{2}$ \\ ${ }^{1)}$ Pengkajian Islam, Sekolah Pascasarjana, Universitas Islam Negeri Syarif Hidayatullah \\ Jakarta, Indonesia; ${ }^{2)}$ kantor Wilayah Kementrian Agama, Kabupaten Buleleng, Bali, Indonesia \\ Korensponden Author: sampaiteguh@gmail.com
}

\begin{abstract}
This study discusses the attitude of corruption based on the perspective of al-Qawaid al-Fiqhiyyah. Corruption is a symptom of a dilemma because of its position not only as an extraordinary crime, but also as a human actualization to feel the hierarchy of needs. This requires a subjective attitudeprimordialist-dogmatic in the form of Islamic views with a jurisprudential (fiqh) approach and perspective of al-Qawaid al-Fiqhiyyah in addressing the two symptoms of the dilemma. The attitude and view of al-Qawaid al-Fiqhiyyah to the punishment of corruption by methodology is done by six categories of rules (major theory) consisting of fourteen applied rules (minor theory). This paper concludes that the attitude of corruption criminal cases can be done with five things; the completion of the Highly Political Cost System, confirmation and tightening of law enforcement, alleviating the economic factors of the government apparatu, to sharpen and culture the hedonism and consumerism, and religious moral preservation.
\end{abstract}

Keywords: corruption; punishment; crime; al-Qawāid al-Fiqhiyyah

\begin{abstract}
Abstrak
Penelitian ini membahas penyikapan tindak pidana korupsi berdasarkan sudut pandang al-Qawāid alFiqhiyyah. Korupsi merupakan gejala yang dilematis karena posisinya tidak hanya sebagai kejahatan luar biasa (Extraordinary Crime), tetapi juga sebagai aktualisasi manusia untuk merasakan hirarki kebutuhan (hierarchy of needs). Hal ini menuntut penyikapan secara subjektif-primordialis-dogmatis berupa pandangan keislaman dengan pendekatan fiqih berperspektif al-Qawāid al-Fiqhiyyah dalam menyikapi dua gejala yang dilematis tersebut. Penyikapan al-Qawāid al-Fiqhiyyah terhadap hukuman tindak pidana korupsi secara metodologi dilakukan dengan enam kategori kaidah (teori mayor) yang terdiri dari empat belas kaidah terapan (teori minor). Tulisan ini menyimpulkan bahwa penyikapan terhadap kasus hukuman tindak pidana korupsi dapat dilakukan dengan 5 hal. Pertama, penyelesaian sistem Highly Political Cost. Kedua, penegasan dan pengetatan terhadap penegakan hukum. Ketiga, mengentaskan faktor ekonomi aparat pemerintah. Keempat, membijaki dan mengarifi budaya hedonisme dan konsumerisme. Kelima, pelestarian moral agama.
\end{abstract}

Kata kunci: korupsi; hukuman; tindak pidana; al-Qawāid al-Fiqhiyyah

\section{A. Pendahuluan}

Korupsi adalah kejahatan sekaligus tindak kriminal yang luar biasa yang menjamur dan terlestarikan dengan baik di beberapa belahan dunia, termasuk negara-negara berkembang ${ }^{1}$ seperti Indonesia. Pandangan Jon S.T. Quah memperkuat hal tersebut (melalui penelitian enam negara di Asia) dengan menyatakan korupsi sebagai way of life yang telah mendarah daging dalam banyak aspek kehidupan bermasyarakat. ${ }^{2}$ Sebagai kejahatan yang mengintimidasi kehidupan manusia, Axel Dreher dan Friedrich Schneider berpendapat bahwa kejahatan

\footnotetext{
${ }^{1}$ Andrei dan Robert secara implisit menyatakan "In some developing countries, such as Zaire and Kenya, it probably amounts to a large fraction of the Gross National Product. Corruption is also common in the developed countries." Lihat Andrei Shleifer dan Robert W. Vishny, "Corruption", Economics, Vol. 108, No. 3 (Agustus 1993), h. 599.

${ }^{2}$ Jon S.T, Quah, Curbing Corruption in Asia: A Comparative Study of Six Countries (Singapore: Eastern University Press, 2003), h. 64.
} 
tersebut harus diantisipasi sedini mungkin. ${ }^{3}$ Di sisi lain, Dieter Haller dan Cris Shore (mendukung pernyataan Elizabeth Harrison) menganggap korupsi sebagai fenomena ketidakstabilan sosial (social pathology) dan kurang maksimalnya kegunaan ilmu dan ranah sosial (social discipline) yang menggerogoti kehidupan sosial. ${ }^{4}$

Awal mula korupsi ditandai dari kehidupan bermasyarakat dengan pergumulan dan organisasi masyarakat dengan segenap perangkat normatifnya mulai mengemuka. Pendapat Hans G. Guterbock (dalam Encyclopedia Brittanica) menyatakan kemunculan persoalan ini diawali dengan keterlibatan hakim dalam gratifikasi pada masa Babylonia dan Assyria. ${ }^{5}$ Sejarah korupsi bukan hal baru dalam konteks kehidupan di Indonesia secara prakonstitusional ${ }^{6}$ hingga konstitusional. ${ }^{7}$ Jejak kasus korupsi dapat ditilik pada tahun 1602 sejak munculnya fakta dan pemlesetan singkatan "Vereenigde Oost-Indische Compagnie" yang berarti "Persekutuan Perusahaan Hindia Timur" menjadi redaksi "Vergaan Onder Corruptie"yang berarti "Bangkrut Karena Korupsi". ${ }^{8}$ Tinjauan pelaku dan regulasi hukum membuktikan dua hal penting berupa diaspora korupsi di seluruh elemen masyarakat dan pembahasan KUHP yang terbatas pada kasus suap saat itu. ${ }^{9}$ Korupsi pada tingkat makro yang melibatkan kaum elit pemerintah orde baru (12 Maret 1967 hingga 21 Mei 1998) diduga menjadi fenomena perdana penyelenggaraan korupsi oleh kelompok yang berkepentingan (interest group). ${ }^{10}$ Awal reformasi dianggap awal keemasan praktik pidana korupsi secara penokohan oleh Jaksa Agung Republik Indonesia yang menghasilkan tindak pidana korupsi baru. ${ }^{11}$ Varian perkembangan fenomena lainnya ialah keterkaitan demonstrasi perdana beberapa kepala desa terhadap dugaan korupsi Kasda (Kas Daerah) yang kosong pada 8 Agustus 2004 menjadi pertimbangan sejarah panjang peradaban korupsi. ${ }^{12}$

Hakikat korupsi tidak hanya sebatas pada "jaminan" (taken for granted) ketidakstabilan dampak negatifnya atau yang disebabkan oleh seseorang. Korupsi adalah refleksi posisi relativistis dimana dirinya dijuluki sebagai "memberi roti" (gift giving) dan mentolerir "budaya menerima" (excused as culturally acceptable). ${ }^{13}$ Korupsi cenderung terkait dengan karakter sosial seperti isu gender, umur, agama, etnis, dan sebagainya yang memungkinkan memainkan suatu peratturan. Di sisi lain, memahami substansi korupsi dengan skala praktis juga tidak terbatas pada wacana pengembangan "kado roti" saja, namun merambah pada wacana dan praksis yang disertai aksi antisipasi administrasi transparan (mounting focus on transparency),

\footnotetext{
${ }^{3}$ Axel Dreher dan Friedrich Schneider, "Corruption and Shadow Economic an Empirical Analysis", Jurnal Springer Vol. 144, No. 1 (Juli 2010), h. 215.

${ }^{4}$ Dieter Haller dan Cris Shore (Ed), Corruption: Anthropological Perspective (London: Pluto Press, 2005), h. 4 .

${ }^{5}$ S.H. Alatas, Korupsi: Sifat, Sebab, dan Fungsi (Jakarta: Media Pratama, 1987), h. 1.

${ }^{6}$ Indonesia pra konstitusional adalah Indonesia dengan kemiripan bentang alam dan iklim yang memiliki impliasi penting tidak hanya dalam pertanian dan perdagangan, namun juga pembentukan Negara. Secara sejarah, pra konstitusional dimaksud untuk masa kolonialisme. M.C. Ricklefs, A History of Modern Indonesia since $c$. 1200, edisi ketiga, (Great Britain: Palgrave Macmillan, 2001), h. 18.

7 Produksi diksi "konstitusional" dalam konteks makalah ini, penulis maksud dengan kemerdekaan 1945 hingga sekarang.

${ }^{8}$ Kebangkrutan VOC (yang tercatat sebagai perusahaan multinasional, MNC pertama pengumpulan modal dari publik melalui bursa efek pertama di dunia, bursa Amsterdam) karena korupsi diambil alih oleh pemerintah Belanda pada 1798. Globethics.net International Secretariat, Etika dan Religiusitas Anti-Korupsi: Dari Konsep ke Praktek di Indonesia (Geneva: Globethics, 2015), h. 12.

${ }^{9}$ Darwan Prinst, Pemberantasan Tindak Pidana Korupsi (Bandung: Citra Aditya Bakti, 2002), h. 7.

${ }^{10}$ Kemitraan bagi Pembaruan Tata Pemerintahan, Survei Nasional Mengenai Korupsi di Indonesia (Jakarta: Tp. 2002), h. v.

${ }^{11}$ Darwan Prinst, Pemberantasan Tindak Pidana Korupsi (Bandung: Citra Aditya Bakti, 2002), h. 9.

12 Taufik Rinaldi, Dewi Damayanti, dan Marini Purnomo, Memerangi Korupsi di Indonesia yang Terdesentralisasi: Studi Kasus Penanganan Korupsi Pemerintah Daerah (Tp.: Justice for the Poor Project: Bank Dunia 2007), h. 89.

${ }^{13}$ Elizabeth Harrison, “Corruption”, Development in Practice, Vol. 17, No. 4/5 (Agustus, 2007): 672-678.
} 
pertanggungjawaban (accountability), dan peraturan hukum (the rule of law). Syed Hussein Alatas berpendapat bahwa esensi korupsi adalah pencurian dengan teknik menipu pada situasi penghianatan terhadap suatu kepercayaan. ${ }^{14}$

Dinamika penentuan koruptor atau individu yang terlibat dalam korupsi adalah problem yang mengalami pengembangan wacana dan fakta. Diskursus koruptor sebagai subjek primer dalam tindak kejahatan luar biasa (extra ordinary crime) menempati perhatian beragam dengan segala subjektifitasnya. Identifikasi koruptor tidak hanya dari kalangan pemerintah semata, namun juga kalangan masyarakat di seluruh elemennya. ${ }^{15}$ Imam ash-Shan'any menunjuk dan membatasi hakim dan pejabat sebagai pihak yang paling bertanggungjawab dalam tindak pidana suap. ${ }^{16}$ Koruptor juga dilihat dari perilaku dalam menjaga relationship dimana hal ini dijelaskan dalam "Webster's Third New International Dictionary" dengan menyandingkan redaksi nepotisme yang berarti hubungan pilih kasih sistem kekerabatan dalam rangka penyalahgunaan aktivitas karir dan ekonomi. ${ }^{17}$ Perspektif yang lebih luas menempatkan koruptor sebagai pihak dengan segala tindakan dan gerakan manusia dalam rangka kebaikan maupun ketidakbaikan memiliki tujuan tersendiri yang menjadi acuan untuk direalisasikan.

Motif, pola, dan bentuk korupsi juga disampaikan dengan pendapat berbeda oleh Munawar Fuad. RA. Munawar Fuad membagi motif, pola, dan bentuk korupsi menjadi tujuh, diantaranya: Pertama, korupsi transaksional, jenis ini dilakukan oleh dua belah pihak yang saling berperan aktif mewujudkan korupsi dimana kedua belah pihak saling diungtungkan; Kedua, korupsi yang bersifat memeras. Janis ini berlangsung dengan pemberian suap oleh pihak pertama kepada pihak kedua agar pihak kedua tidak melakukan hambatan dan rintangan terhadap pihak pertama; Ketiga, korupsi yang bersifat ontogenik. Korupsi jenis ini melibatkan pihak yang berkepentingan semata seperti anggota legislatif yang mendukung rancangan undang-undang yang menguntungkan dirinya semata; Keempat, korupsi defensif. Jenis ini bersifat penawaran seperti seseorang yang menawarkan suap terhadap hakim untuk membela dirinya agar mendapatkan pengurangan, bahkan pembebasan atas segala dakwaan hukum yang menimpanya; Kelima, korupsi dengan karakter investasi. Hal ini dapat diilustrasikan dengan pemberian layanan barang atau jasa dengan maksud mendapatkan "uang terimakasih" atas pelayanan yang ia lakukan; Keenam, korupsi yang berkarakter nepotisme. Jenis ini terjadi melalui pelibatan sistem kekeluargaan yang dianggap memiliki kedekatan psikologis-sosialis untuk meraih posisi jabatan publik atau dalam rangka mendapatkan perlakuan khusus tertentu; Ketujuh, korupsi suportif. Jenis ini dapat dimengerti dengan tidak melibatkan uang, barang, atau jasa apapun secara langsung. Hal ini dapat dilihat dari pembiaran terhadap aktifitas dan budaya korupsi yang terjadi dengan sikap masa bodoh atau apatis. ${ }^{18}$

Korupsi dalam kacamata generik adalah kejahatan sosial yang membahayakan seluruh dimensi kehidupan. Kacamata hukum secara generik ataupun hukum Islam beserta pirantipirantinya (qawāid fiqhiyyah dan perbedaan mazhab fikih) secara ideologis-dogmatis sebagai pendekatan "hitam-putih" adalah suatu penyikapan dan pendekatan yang tidak mentolerir ruang dialogis. Pada tataran realitas, selalu ada kedialogisan dalam ketidakdialogisan; atau "abu-abu" selalu dilahirkan dari rahim "hitam-putih". Lebih jauh, abu-abu mana yang hendak digunakan? Fikih sekterian menjadi jawaban atau pertikaian? Dialogisasi dalam perbedaan

${ }^{14}$ M. Nurul Irfan, Korupsi dalam Hukum Pidana Islam (Jakarta: AMZAH, 2011), h. 34. Lihat juga Baharuddin Lopa, Masalah Korupsi dan Pemecahannya, Cetakan I (Jakarta: PT. Kipas Putih Aksara, 1997), h. v.

${ }^{15}$ Umar Sulaiman, Korupsi dan Dialektika Manusia Sempurna: Sebuah Analisis Terhadap Peranan KPK dalam Pemberantasan Korupsi (Jakarta: Sekolah Pascasarjana Universitas Islam Negeri Syarif Hidayatullah, 2016), h. 10-16.

${ }^{16}$ Muhammad bin Ismail al-Shan'any, Subulus Salam (Beirut: Dar el-Fikr, 1990), h. 124.

${ }^{17}$ RA. Munawar Fuad, Masalah Korupsi di Indonesia: Telaah dari Perspektif Cendekiawan Muslim (Jakarta: Program Pascasarjana IAIN Syarif Hidayatullah, 1998), h. 26.

${ }^{18}$ RA. Munawar Fuad, Masalah Korupsi di Indonesia: Telaah dari Perspektif Cendekiawan Muslim (Jakarta: Program Pascasarjana IAIN Syarif Hidayatullah, 1998), h. 25-27. 
fikih terhadap korupsi berlangsung sekejap-sesaat atau sepanjang masa? Penelitian ini dilakukan untuk membahas penyikapan tindak pidana korupsi berdasarkan sudut pandang alQawāid al-Fiqhiyyah.

\section{B. Redaksi dan Definisi Korupsi dan Dialektika Landasan Alquran-Hadis}

Dinamika perkembangan diksi "korupsi" mengalami sedikit pertentangan. Diksi "korupsi" berasal dari bahasa latin corruptio atau corruptus yang tersebar dan teradopsi oleh beberapa negara di Eropa seperti Inggris dan Prancis Corruptio dan Belanda Corruptie. ${ }^{19}$ Andi Hamzah dan Adami Chazawi tidak setuju dan menyatakan bahwa korupsi dalam bahasa Inggris disampaikan dengan redaksi corruption atau corrupt, dalam bahasa Prancis disampaikan dengan redaksi corruption, dan dalam bahasa Belanda disampaikan dengan redaksi corruptie atau korruptie. ${ }^{20}$ Diksi ini kemudian mengalami diaspora oleh imperialisme dan mengkristal menjadi diksi yang resmi di Indonesia berupa "korupsi". Diksi "korupsi" berasal dari bahasa latin corruptio atau corruptus yang berarti "busuk", "rusak", "menggoyahkan", "memutar balik", "menyogok", “orang yang dirusak", "dipikat", atau "disuap". ${ }^{21}$ Korupsi adalah penyalahgunaan amanah untuk kepentingan pribadi. ${ }^{22}$

Perhatian agama terhadap korupsi yang tidak sepi sejak zaman klasik hingga terkini telah mengkristal dan mendapat respon teologis-dogmatis-ideologis. Normatifitas menjadi stimulan yang secara aktif mempengaruhi totalitas keyakinan pemeluknya. Dogmatisasi dan ideologisasi agama yang menyatakan korupsi sebagai sikap indisipliner diperkuat dengan asas normatifitas agama yang mencerminkan wilstanchung (diambil dari bahasa Belanda yang berarti "pandangan dan pedoman hidup" dengan dua alat berupa Alquran dan Hadis dalam rangka menjaga kemaslahatan.

Kehadiran Alquran secara (tematis) dalam merespon korupsi dibuktikan dengan QS. 2:188, 3:161, 4:29, dan 5:62. Asmawi menyatakan bahwa entry point QS. 3:161 adalah konsistensi menjaga "hitam-putih" yang dicerminkan dalam produk haramnya terhadap diksi al-gulul. Hal tersebut didasarkan dari stimulasi yang diaplikasikan dengan klausa "al-Tarhib" atau "al-

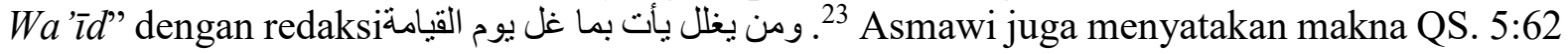
terfokus pada hukum haram pada frase ahl al-suht yang dibuktikan dengan aplikasi klausa “pencelaan” (al-ta'bìr bi al-dzamm) berupa redaksi klausa لبئس ما كانو ا يعملون.

Kualifikasi al-gulul diterangkan dalam Hadis Abu Dawud ${ }^{24}$ sebagai respon terhadap QS. 3:161

$$
\text { من استعملناه على عمل فرزقناه رزقا/ فما أخذ بعد ذلك فهو غلول (رواه أبو داود) }
$$

${ }^{19}$ Tri Andrisman, Pemberantasan Tindak Khusus Di Luar KUHP (Bandar Lampung: Universitas Lampung, 2010), h. 37.

${ }^{20}$ Andi Hamzah, Pemberantasan Korupsi melalui Hukum Nasional dan Internasional, Cet. II, (Jakarta: Raja Grafindo Persada, 2005), h. 4. Lihat Adami Chazawi, Hukum Pidana Materiil dan Formiil Korupsi di Indonesia, Cet. II, (Malang: Bayu Media, 2005), h. 1.

${ }^{21}$ Tri Andrisman, Pemberantasan Tindak Khusus Di Luar KUHP (Bandar Lampung: Universitas Lampung, 2010), h. 37.

${ }^{22}$ Syamsul Anwar, Fikih Anti Korupsi: Perspektif Ulama Muhammadiyah Majelis Tarjih dan Tajdid PP. Muhammadiyah (Jakarta: Pusat Studi Agama dan Peradaban, 2006), h. 10.

${ }^{23}$ Abu al-Fidaa' Ismail ibn 'Umar ibn Katsir, Tafsir Alquran al-'Azim, tahqiiq Saami ibn Muhammad Salaamah (Riyad: Daar Tayyibah li al-Nasyr wa al-Tauzi’, 1999), Juz ke-2, 151. Lihat Disertasi, Asmawi, Teori Maslahat dan Relevansinya dengan Perundang-Undangan Pidana Khusus di Indonesia (Jakarta: Sekolah Pascasarjana UIN Syarif Hidayatullah, 2009), h. 95. Lihat juga Syams al-Diin al-Qurtubi, al-Jaami' li Ahkam Alquran (Beirut: Daar al-Fikr, t.th.), Juz ke-4, 258. Lihat juga Abu Ja'far al-Tabari, Jami' al-Bayan fi Ta'wil Alquran, tahqiiq Ahmad Muhammad Syaakir (Bairut: Mu'assasat al-Risaalah, 2000), Juz ke-7, 355.1

${ }^{24}$ Hadis tersebut diriwayatkan oleh Abuu Daawud yang berasal dari Buraidah, dari Bapaknya. Sulaiman ibn al-Asy'asy al-Sijistani (Abuu Daawud), Sunan Abi Daawud, Juz ke-9, hadis nomor 2945, 59. Lihat juga Disertasi, Asmawi, Teori Maslahat dan Relevansinya dengan Perundang-Undangan Pidana Khusus di Indonesia (Jakarta: Sekolah Pascasarjana UIN Syarif Hidayatullah, 2009), h. 95. 
Barang siapa yang kami angkat sebagai pegawai untuk suatu tugas pekerjaan, kemudian kami berikan kepadanya gaji, maka segala yang dia ambil di luar itu merupakan gulul (H.R. Abu Dawud).

Landasan Hadis dalam menyikapi korupsi diawali dengan varian redaksi. Nur Achmad menyebutkan enam fenomena redaksionis yang muncul dalam hadis nabi Muhammad berupa Gulul, Hadiyyah, Risywah, Suht, Bai'at al-Imām li al-Dunyā, dan Jaur al-Qadi au al-Imam. ${ }^{25}$ Inventarisir dan pemetaan yang dilakukan Nur Achmad meliputi tiga Hadis gulul secara umum, empat belas Hadis gulul al-ganimah, sembilan Hadis gulul al-sadaqah dan hadiyyah al'ummal, tiga Hadis risywah, dua Hadis suht, satu Hadis bai'at al-imam li al-dunya, 5 Hadis jaur al-qadi aw al-imam. ${ }^{26}$

\title{
B.1 Qawāid al-Fiqhiyyah: Pendekatan Konsepsional
}

Problematika yang dinamis, terlebih bersifat kasuistis merupakan wujud perkembangan komplesitas peradaban manusia. Islam secara subyektif, terlebih pendapat tokoh Islam secara fanatik-primordialis-subyektif turut andil dalam menyelesaikan beberapa kasus seperti korupsi dengan perangkat operasional tertentu seperti Qawāid al-Fiqhiyyah.

Penulis menyajikan beberapa kaidah fikih yang relevan dalam menyikapi kasus korupsi. Kaida-kaidah fikih tersebut dijabarkan sebagaimana berikut:

a. Memprioritaskan kepentingan positif-konstruktif (maslahah) disbanding kepentingan negatif-destruktif (al-Mafasid)

"Meraih kemaslahatan dan menolak kemudaratan"

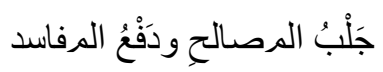

b. Lima kaidah pokok (Al-Qawāid al-Khamsah) yang meliputi:

"Segala hal didasarkan pada maksud/niat/I'tikad"



"Kemudaratan harus dihilangkan"

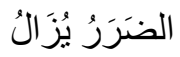

\begin{abstract}
“Kemeratan harus dihilangken"
\end{abstract}
"Keyakinan tidak dapat dihilangkan dengan keraguan"

اليقين لا يزال بالثكك

"Kejakinan tidak dapat dihilangkan dengan keraguan"

"Kesulitan mendatangkan kemudahan"

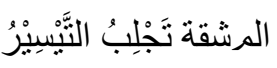

العادةُ مُحَكَّمَةُّ

"Adat atau kebiasaan dapat dijadikan pertimbangan dalam menetapkan suatu hukum"

"Tidak ada pahala kecuali dengan niat"

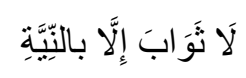

c. Penjabaran lima kaidah pokok di atas dengan dua kaidah, sebagaimana berikut:

\footnotetext{
${ }^{25}$ Nur Achmad, Pencegahan Korupsi dalam Perspektif Hadis: Studi Hadis Korupsi dalam Kutub al-Sittah (Jakarta: Sekolah Pascasarjana Universitas Islam Negeri Syarif Hidayatullah, 2007), h. 81-101.

${ }^{26}$ Nur Achmad, Pencegahan Korupsi dalam Perspektif Hadis: Studi Hadis Korupsi dalam Kutub al-Sittah (Jakarta: Sekolah Pascasarjana UIN Syarif Hidayatullah, 2007), h. 103-128.
} 
"Kemaslahatan tidak bisa dihilangkan dengan kemudaratan lagi"

$$
\text { الضرورات تُبِيْحُ الْرَخْظُوْرَات }
$$

\section{"Kemudaratan harus ditolak (dihilangkan) sekedarnya"}

$$
\text { الضَّرَرُ يُدْفَعُ بِقَدْرِ الإمركَانِ }
$$

d. Varian kaidah dalam disiplin hukum (lebih spesifik bukan pada ibadah, namun pada mua $>$ malah) tertentu:

\section{"Kerugian dibebankan karena orang mendapatkan keuntungan",27}

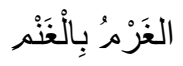

e. Kaidah fungsional dalam analisis konflik yang dijabarkan dengan relasi dua kaidah sebagaimana berikut:

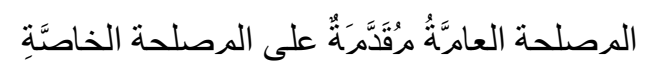

"Kemaslahatan publik didahulukan daripada kemaslahatan pribadi"

"Tidak memudaratkan dan tidak dimudaratkan"

f. Kaidah yang bersifat antisipatif

"Menolak Mafsadah didahulukan daripada meraih maslahat"

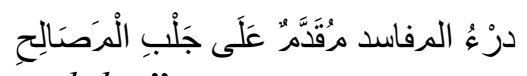

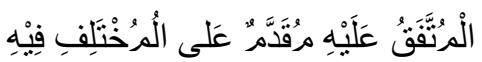

"Apa yang disepakati diprioritaskan dibandingkan dengan apa yang diperdebatkan/diperselisihkan"

\section{B.2 Penerapan Ijtihad dalam Penentuan Hukum}

Korupsi yang dicitrakan sebagai kejahatan luar biasa (extra ordinary crime), kejahatan terhadap manusia (crime against humanity), dan kejahatan terorganisir (organized crime) membutuhkan suatu penyikapan dan penindakan tertentu. Penerapan ijtihad sebagai solusi dalam ranah agama (Islam) menjadi sebuah keniscayaan untuk merespon sesuatu yang ada di luar teks (Alquran dan Hadis). Hal ini senada dengan fungsi ijtihad sebagai usaha untuk menyelidiki hukum Islam secara ilmiah yang digunakan dalam rangka memahami respon atau kehendak Allah terhadap kemunculan permasalahan hukum. ${ }^{28}$ Pandangan ini diperkuat dengan pendapat Fathurrahman Djamil ${ }^{29}$ yang menyatakan bahwa ijtihād yang salah satu caranya dilakukan dengan penerapan kaidah fiqh mampu menyelesaikan masalah-masalah baru (baik baru secara noumena-fenomena maupun baru secara perkembangan motif-modus) seperti korupsi.

Korupsi transaksional merupakan fenomena unik yang perlu disikapi bersama karena karakternya dualistis, keterlibatan dua pihak dengan simbiosis mutualismenya. Korupsi jenis ini sangat erat kaitannya dengan beberapa kaidah fiqih seperti yang hendak disebutkan sebagaimana berikut: Pertama, kaidah جَلْبُ الرصالح ودَفْعُ الرفاسد dianggap relevan karena entry point yang disampaikan adalah memprioritaskan kemaslahatan (atau kepentingan bersam جَلْبُ

\footnotetext{
${ }^{27}$ Dapat juga diartikan "resiko itu menyertai manfaat". Maksud dari kaidah tersebut adalah dampak dan resiko yang ditanggung seseorang yang dihadapi jika ia memanfaatkan sesuatu.

${ }^{28}$ Ruhimin Affandi Abdul Rahim,’'Ijtihād dalam Institusi Fatwā di Malaysia: Satu Analisis”, Jurnal Syariah, Vol. 17, No. 1 (2009), h. 198.

${ }^{29}$ Fathurrahman Djamil, Metode Ijtihad Majlis Tarjih Muhammadiyah (Jakarta: Logos Wacana Ilmu, 1995).
} 
الرصالح untuk mengakomodir kepentingan banyak pihak dan bukan dua pihak semata. Entry point دَفُْع الرفاسد menjadi pertimbangan tersendiri karena kepentingan dua belah pihak yang saling bersinergi dalam korupsi merupakan usaha penyalahgunaan wewenang (abuse of power). Kaidah antitesa terhadap kaidah tersebut adalah العادةُ مُحَكَمَ dengan alasan bahwa kebiasaan dan budaya korupsi bisa saja menghadirkan produk hukum berupa kebijakan yang bernilai maslahah. Hal yang perlu dipertimbangkan dalam memahami dan menerapkan kaidah ini adalah tidak adanya standard yang jelas dan transparansi transaksi tersebut agar diketahui oleh public. Standar dan transparansi yang meragukan merupakan gangguan tehnis (technical mistakes) yang fatal dalam mewujudkan kemaslahatan dan menghindari kemudaratan.

Korupsi yang bersifat memeras adalah hal yang tidak tabu dalam cakrawala umum maupun pandangan agama. Keegoisan pihak pertama dalam menyuap pihak kedua agar tidak dihambat atau dirintangi merupakan kecurangan kompetisi atau persaingan yang tidak sehat. Kaidah yang diterapkan dalam tipologi kasus korupsi ini adalah الغَرْمُ بِالَْغْنَ dengan pertimbangan bahwa pihak yang melakukan rintangan terhadap pihak pertama adalah tugas normatif yang harus dilakukan untuk menghindari atau setidaknya meminimalisir tindak kejahatan atau potensi terjadinya tindak kejahatan. Penerapan rintangan dan hambatan terhadap pihak pertama adalah kewajiban yang didasarkan pada keuntungan yang didapatkan pihak pertama dalam menjalankan tahapan-tahapan pelaksanaan maksu dan niatnya. Sebalinya, penerapan rintangan dan hambatan (secara normatif sekalipun) dengan tujuan untuk memperoleh keuntungan pribadi merupakan aktifitas kerja yang indisipliner dan tidak bisa ditolerir karena memanfaatkan peraturan yang berlaku untuk memunculkan potensi tindak kejahatan (korupsi) yang pada akhirnya melahirkan generasi prestisius dalam bidang korupsi. Kaidah antitesa

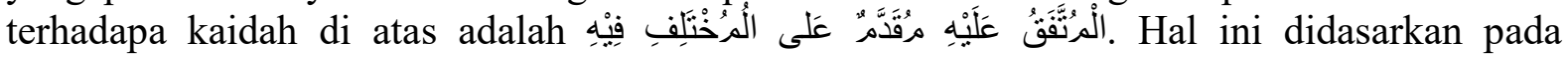
kesepakatan yang dilakukan oleh penyuap (pihak pertama) dan penerima suap (pihak kedua). Hal yang kontras juga terjadi dengan kemunculan perdebatan terkait suap agar tidak terjadi hambatan dengan alasan birokrasi dan oknum pegawai atau pekerja yang tidak professional dalam hal melayani kepentingan umum di tiap-tiap unit kerjanya. Hal ini mengakibatkan munculnya fenomena budaya baru berupa pelayanan professional yang diterapkan berdasarkan ada atau tidaknya suap yang diberikan oleh pihak pertama yang diawali dengan permintaan untuk menyuap secara tidak langsung (biasanya dengan indikasi kinerja-birokrasi-administrasi yang dibuat bertele-tele, dengan durasi lama, atau dengan pelayanan fisik yang tidak ramah).

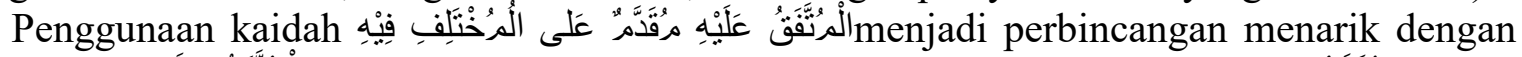

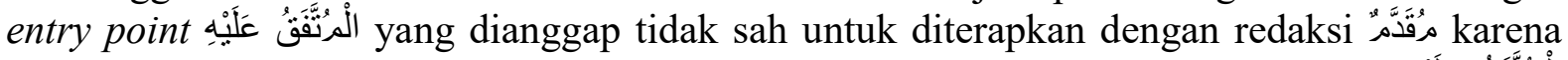

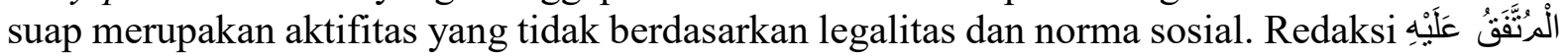
yang berkonotasi korupsi maupun suap tidak memiliki legalitas apapun secara normatif dan

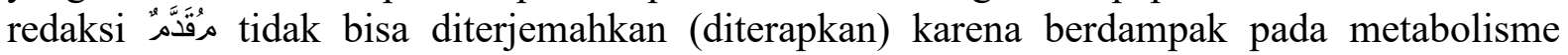
keharmonisan sosial.

Tipologi korupsi ketiga berupa korupsi ontogenik merupakan spesifikasi lagislatif dengan melibatkan pribadi (sendiri) sebagai pelaku utama menjadi isu yang debatable. Kaidah yang

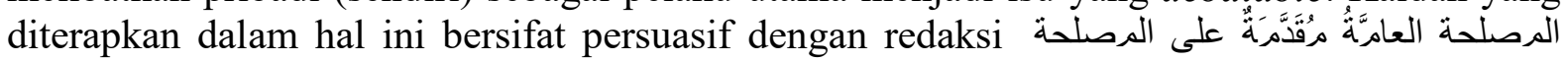
الخاصيَّة umum. Tafsir pertama menyatakan bahwa anggota dewan legislatif merupakan representasi suara rakyat dan secara otomatis anggota-anggota dewan tersebut sebagai kepentingan umum (الرصلحة العامَّة) ). Tafsir kedua menyatakan bahwa fakta keterlibatan korupsi yang dilakukan oleh anggota dewan dewasa ini merupakan indikasi kuat bahwa kinerja kelegislatifan para anggota dewan tidak berdasarkan aspek الرصلحة العارَّة (dari, oleh, dan untuk rakyat), namun berdasarkan

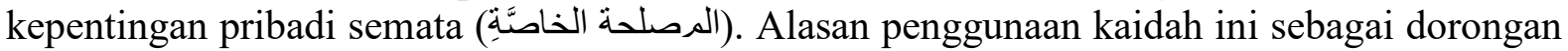
persuasif dalam menyampaikan, mengingatkan, dan menegur tindak pidana korupsi berupa 
dukungan anggota dewan dalam memuluskan dan mendukung rancangan undang-undang yang menguntungkan kepentingan mereka semata dan bukan kepentingan kebangsaan secara makro.

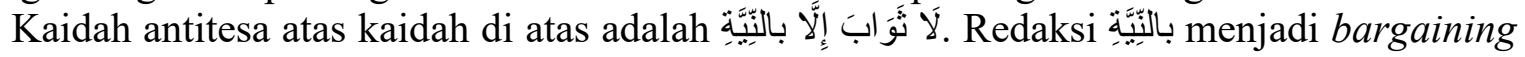
position yang digunakan untuk mengklaim serta memperjuangkan nasib dan kepentingan rakyat. Redaksi تئَابَ merupakan apresiasi yang dimaknai sebagai kepuasan batin dan sosial (penghormatan) jika anggota dewan mampu meng-goal-kan Undang-Undang Namun terminologi kepentingan rakyat tidak bisa dimaknai secara telanjang dalam percaturan hegemoni yang menghasilkan dua pertanyaan, "rakyat yang mana?" "UU yang menguntungkan partai mana?"

Korupsi defensif (biasa terjadi dalam kasus peradilan yang dilakukan pihak saksi, terduga, tersangka, atau terdakwa terhadap hakim) adalah tipologi korupsi dimana pihak penyuap menawarkan suap terhadap hakim untuk penghapusan putusan hakim atau pengurangan putusan hakim. Kaidah yang diterapkan adalah الغَرْمُ بِالْغَنْر karena saksi, terduga, tersangka, atau terdakwa dianggap mendapatkan keuntungan melalui melakukan kesalahan atau setidaktidaknya mengetahui tindak pidana-perdata. Pihak saksi, terduga, tersangka, dan terdakwa tidak berhak menyuap hakim dalam rangka meringankan bahkan melepaskan kasusnya karena dunia peradilan merupakan ajang penerapan normativitas secara realita dengan menjunjung nilai kesamaan di mata hukum dan asas objektif. Kaidah antitesa dalam merespon kaidah di atas adalah اليقين لا يز ال بالثك dengan alasan kewajiban membela diri dan mempertahankan hak serta kebenaran jika posisi saksi, terduga, tersangka, atau terdakwa tersebut disudutkan bahkan ditemukan adanya indikasi yang merugikan dirinya oleh hakim. Keyakinan yang dihadapi saksi, terduga, tersangka, dan terdakwa adalah hak yang harus dipertahankan dibandingkan dengan prosesi meja peradilan yang bersifat keragu-raguan. Namun, bagaimanapun hak, kebenaran, dan keyakinan yang dipertahankan tidak bisa diwujudkan atau diterapkan dengan menyuap hakim karena hal ini masuk dalam kategori dunia kriminal, korupsi.

Korupsi yang bersifat investasi merupakan tindakan mentalistis-asumtif-subyektif yang dilakukan atas dasar keinginan memperoleh sesuatu yang lebih dari yang semestinya. Profesionalitas kerja tidak hanya didukung dari tuntutan beserta penerapan hasil pekerjaan yang memuaskan, namun juga harus ditunjang dengan perasaan mencintai pekerjaan yang dilakukan dan mengerjakan sesuatu dengan penuh rasa senang-suka tanpa mengharapkan "imbalan lebih". Kaidah yang digunakan dalam kasus sekaligus tipologi korupsi ini adalah الأمور بمقاصدها dengan alasan bahwa niat, keinginan, atau i'tikad "memperoleh sesuatu yang lebih" adalah stimulasi terjadinya tindak pidana korupsi berupa suap. Walaupun hanya sekedar stimulasi asumtif-subyektif-mentalistis, namun keberadaannya merupakan praktik pelestarian

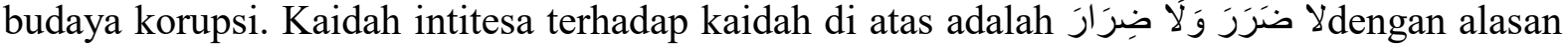
bahwa pengharapan merupakan hal yang sah, dan tidak melanggar hukum, serta tidak dapat menghadirkan kemudaratan dan pengharapan bukan merupakan suatu hal yang dimudaratkan. Namun, hal yang terpenting atas tipologi ini adalah peningkatan kualitas hidup yang berkualitas menjadi prioritas bagi seluruh manusia baik secara biologis-praktis-realistis maupun secara mentalistis.

Korupsi berjenis nepotisme merupakan hubungan intervensi kekerabatan dalam ranah psikologi-sosial menjadi kajian menarik untuk dibaca dan dianalisa. Tipologi dengan tujuan perolehan jabatan dan perlakuan khusus ini merupakan korupsi yang dilakukan secara kolektif


kasus seperti ini. Hal ini didasarkan dengan alasan bahwa tali persaudaraan-pertemanan tidak bisa dijadikan landasan untuk melakukan persekongkolan kejahatan. Kaidah yang menolak kaidah tersebut di atas sekaligus membenarkan korupsi yang bersifat nepotisme adalah الرصلحة dengan alasan bahwa yang diperjuangkan adalah kepentingan lebih dari satu orang dan bukan kepentingan pribadi atau individual (satu orang saja). Namun hal yang perlu dipahami dalam hal ini adalah "kepentingan lebih dari satu orang" yang mana? 
Dari kelompok mana? Dari partai mana? Dari dinasti mana? Dari jalur kekerabatan siapa? Tentu semua itu hanyalah pemuasan terhadap dan oleh sekelompok tertentu saja dan tidak merepresentasikan kepentingan universal (masyarakat yang lebih umum).

Korupsi suportif sebagai tindakan pembiaran (korupsi yang tidak melibatkan uang, barang, dan jasa) menjadi dinamika tersendiri. Pangkal budaya korupsi ini menjadi terpelihara dan terlestarikan adalah keberadaan mentalitas yang kontra produktif berupa sifat dan sikap masa bodoh atau apatis. Kaidah yang digunakan untuk membijaki kasus ini adalah الضَّرَرُ يُدْفَعُ بِقَدْرِ الإمكَانِ Pemilihan kaidah tersebut dilandasi dengan alasan bahwa menolak dan mencegah kemudaratan atau keburukan (kejahatan) adalah kewajiban semua orang sesuai dengan kemampuannya masing masing yang ditunjukkan dengan penekanan dan kemunculan diksi ini. Kaidah yang membantah kaidah tersebut di atas dan mendukung sikap apatis


alasan bahwa setiap tindak kejahatan-keburukan berkonsekuensi fatal jika dilarang dan dicegah. Konsekuensi buruk tersebut tidak hanya menimpa diri sendiri, keluarga, karir, atau orang-orang terdekat, namun juga membahayakan aset pribadi yang dimiliki oleh orang yang mencegah-menasehati-menolak kajahatan-korupsi-keburukan. Namun, hal yang perlu diingat adalah kemudahan (dengan diksi التنَّْنِيْرِ) yang diharapkan oleh orang-orang apatis untuk menghindari konsekuensi buruk (kesulitan atau dampak negatif yang dibahasakan oleh hadis tersebut dengan diksi الرشقة) merupakan tindakan egois yang mementingkan keselamatan diri sendiri atau kerabat terdekatnya saja, dan tidak mementingkan keselamatan dan bahaya yang akan ditimpa masyarakat umum, jika kasus korupsi itu terjadi, berlanjut dan menjadi tradisi dalam kehidupan sehari-hari yang akan berdampak fatal bagi generasi selanjutnya.

\section{Praktik Pemberantasan Tindak Pidana Korupsi : Antara Kepalsuan dan Tuntutan}

Diaspora korupsi yang massif dalam realitas empirik telah didukung beberap mitos yang direstui dan diamini sebagai suatu kebenaran. Pertama, jujur pangkal hancur. Kejujuran merupakan komoditas langka di negeri para maling. Orang jujur diibaratkan seperti memegang batu-bara. Probabilitas yang terlahir adalah selamat dengan membuangnya atau terbakar. Orang yang bertahan dalam kejujuran tersapu oleh sistem yang korup, sosial, bahkan sistem kekerabatan, dan sejarah peradaban manusia lokalistis terkini. Orang yang mampu bertahan dengan kejujuran merupakan fenomena prestisius. Di sisi lain, jangan menjadi pihak PHP (pemberi harapan palsu) yang memberikan harapan perubahan sistem dan reformasi birokrasi korup karena orang yang jujur tidak pernah mendapatkan peluang.

Kedua, korupsi merupakan seni. Seni dan budaya terindah di negara kita adalah korupsi. Posisi korupsi dicitrakan sebagai seni, maka kejujuran adalah gambar rekaan-manipulatif. Aplikasi seni dalam hukum melibatkan unsur-unsur internal seperti kemampuan lobi, strategi mendekati otoritas hukum, seni melindungi kerahasiaan, dan seni pemberian jaminan keamanan-hukum-status terhadap pihak yang terlibat di dalamnya. Hal inilah yang menyebabkan kehadiran pemandangan praktik tindak pidana korupsi yang dilakukan secara berjamaah. Kerahasiaan sebagai syarat sekaligus rukun korupsi yang diterapkan masyarakat secara umum harus diterapkan dengan adil dalam hal pembagian "kue" dan jaminan keamanan. Jika hal ini tidak terlaksana, maka tidak heran pemberlakuan pribahasa puitis (karena nila setitik, rusak susu sebelanga) yang berarti "mati satu, mati semua"sebagai efeknya.

Ketiga, korupsi merupakan simbol kecerdasan dalam kejahatan. Kecerdasan dalam ranah korupsi sering diterjemahkan dalam berbagai bentuk seperti: 1. Sejauhmana memaksimalkan potensi kecerdasan dalam memanfaatkan (korupsi) uang negara semaksimal mungkin, 2. Mampu menunaikan uang negara sebelum waktunya (tutup tahun), 3. Menyusun anggaran dan LPJ (Laporan Pertanggungjawaban) fiktif proyek atau program tertentu dengan mengerahkan segenap imajinasinya, dan 4. Meningkatkan kualitas silaturahim dalam mempermulus usaha korupsinya. Kecerdasan kejahatan tinggi dalam pelaksanaan korupsi membutuhkan 
kemampuan pembacaan yang jeli dalam mencari celah hukum. Pembuktiannya, koruptor kelas kakap memiliki kecerdasan kejahatan tinggi karena mereka tidak pernah mampu untuk ditangkap dan dipenjarakan sementara orang yang tidak mampu menyusun anggaran dan LPJ mendapat label "bodoh."

Keempat, mitos jawa, "aji mumpung”. Mitos ini menekankan pada penggunaan "waktu luang atas waktu sibuk dan bersehat-ria sebelum datang penyakit dan kecemasan hilangnya kewenangan, pengaruh, jabatan, dan kekuasaan saat seseorang tidak lagi duduk di posisi puncaknya. Tidak adanya jaminan menjadi seseorang yang kaya seumur hidup menjadi alasan pokok dalam memaksimalkan jabatan dengan memperkaya diri yang salah satunya dengan tindakan korupsi.

Upaya pemberantasan korupsi dalam ranah praksis dan perumusan kebijakan yang melibatkan seluruh pihak, sektor, dan komponen dari pemerintah maupun nonpemerintah dilakukan dengan massif dan merata. Hal tersebut sejalan dengan fakta korupsi yang tidak hanya didominasi oleh perilaku para pejabat dan elit pemerintah semata, namun kolektif hampir di seluruh lapisan masyarakat sipil. Hal ini sesuai dengan hukum ekonomi dimana supply hadir atas tuntutan demand. Secara ringkas, penanggulangan dinamika korupsi hanya mampu diatasi ketika sistem sosial dan sistem formal tidak memberi ruang dialog dan toleransi kepada koruptor serta mematikan mata rantai indisipliner yang biasa dilakukan oleh stakeholder dan shareholder.

Solusi pertama adalah pendekatan dalam penyelesaian sistem highly political cost. Sistem ini terjadi secara periodik-temporal dimana pemilu sebagai event yang ditunggu-tunggu dalam mengundi nasib melalui pengeluaran pembiayaan kampanye yang tidak sedikit, baik di tataran pemerintah legislatif maupun eksekutif. Tingginya harga politik dalam memperebutkan kursi pemerintahan secara orientasi selalu berbanding lurus dengan hasil yang didapatkan seorang calon apabila dia terpilih menjadi salah satu unsure penyelenggara negara dengan melestarikan budaya korupsi melalui penyelahgunaan kewenangan dan kebijakan (abuse of power). Harga yang tinggi dalam kontes pencarian bakat korupsi dalam event pemilu agaknya tidak hanya terjadi pada level nasional, namun juga daerah.

Solusi kedua adalah penegasan dan pengetatan terhadap penegakan hukum. Penegakan hukum dalam ranah korupsi secara khusus dilakukan oleh Kepolisian dan Komisi Pemberantasan Korupsi (KPK). Kedua instansi yang namanya melambung secara prestisius dari apresiasi masyarakat berbanding terbalik dengan asumsi-asumsi publik yang menyatakan bahwa keduanya cenderung tebang pilih $^{30}$ dalam penanganan kasus, khususnya pada Operasi Tangkap Tangan (OTT). Stimulasi penegakan hukum harus dilakukan dengan tegas dan berani dengan perumpamaan seperti: 1 . Bersih-bersih birokrasi yang diagendakan rutin sebulan dua kali, 2. Penerapan hukum yang tidak tebang pilih, baik yang ditujukan kepada seluruh instansi (dari kecamatan hingga ibu kota) pemerintah dan instansi penanggulangan-pemberantasan korupsi (seperti kejaksaan, kepolisian, KPK, pengadilan, dan hakim), 3. Sanksi hukum tanpa remisi, dan 4. Sanksi hukum yang berat seperti hukuman mati bagi koruptor yang merugikan negara dengan nominal 5 milyar, pencabutan hak pegawai negeri dan hak politik bagi koruptor yang terbukti merugikan negara senilai minimal seratus juta, dan hukuman seumur hidup bagi koruptor yang terbukti merugikan negara minimal dua milyar.

Solusi ketiga adalah mengentaskan faktor ekonomi aparat pemerintah. Secara kacamata professional, pendapat pegawai negeri sipil ada dalam takaran memprihatinkan jika dibandingkan dengan standar kebutuhan sosial keluarga atau rumah tangga mereka. Kecacatan

\footnotetext{
${ }^{30}$ Fatwa hukuman mati bagi koruptor dikeluarkan beberapa ulama Nahdlatul Ulama (NU) dan kematian para koruptor tidak perlu dishalati. Fatwa majelis tarjih Muhammadiyah juga menyatakan bahwa korupsi adalah syirik Akbar yang tidak ada pengampunan dosa oleh Allah. Lihat, Lukman Hakim (2012), "Model Integrasi Pendidikan Anti Korupsi dalam Kurikulum Pendidikan Islam”, Jurnal Pendidian Agama Islam-Talim, Vol. 10 , No. 2: 144.
} 
seperti ini memunculkan libido korupsi atau setidak-tidaknya melakukan interaksi kolusif dan rekayasa administrasi (atau yang biasa disebut dengan manipulasi), serta nepotisme.

Solusi keempat adalah membijaki dan mengarifi budaya hedonisme dan konsumerisme yang menstimulasi kemapanan life style dan menepis praktik-ajaran hemat. Budaya kontra produktif yang digandrungi masyarakat saat ini secara umum dan kalangan ABG-remaja secara khusus merupakan imbas dari kebebasan media yang merangsang hasrat dan pikiran masyarakat secara perlahan namun masif. Pembijakan kasus demikian hanya dapat ditanggulangi dengan strategi yang tepat seperti penyaluran energi ke arah positif-produktifvisioner yang sesuai dengan minat dan bakat masyarakat. Di sisi lain, harus ada regulasi nasional dalam rangka pengenalan antar budaya seperti study tour nasional (yang diselenggarakan pemerintah dalam memberangkatkan beberapa kontingen berdasarkan pulau tertentu menuju pulau tertentu yang berlainan selama dua minggu misalnya) dan cultural road (dimana setiap kontingen yang terdiri dari satu provinsi mengikuti program pengenalan pagelaran musik, tarian, kuliner, pakaian adat, senjata adat, hingga produk-produk sastrabudaya kesukuan).

Solusi kelima adalah pelestarian moral keagamaan. Moral keagamaan sebagai benteng terakhir dari aktivitas negatif merupakan solusi persuasif yang dapat diterima (secara umum) oleh segenap lapisan masyarakat. Perbuatan yang bersifat intolerir, inkonsisten, dan indisipliner (termasuk korupsi) dapat diisolasi bahkan dihapus serta-merta dengan suatu ingatan dan panggilan hati yang mengumandangkan dua diksi (antara "dosa" dan "neraka") dalam ajaran agama Islam dan Kristen, serta konsep karma (sirkulasi sebab-akibat atau kausalitas) dalam agama Hindu dan Budha.

\section{Penutup}

Tipologi korupsi dapat dibuktikan dengan adanya beragam jenis korupsi seperti korupsi transaksional, korupsi yang bersifat memeras, korupsi ontogenik, korupsi defensif, korupsi yang bersifat investasi, korupsi berjenis nepotisme, dan korupsi suportif. Penyikapan beragam jenis korupsi dilakukan melalui kaidah fiqhiyyah dalam penelitian ini. Korupsi transaksional disikapi dengan kaidah jalbu al-Mașālị̣ wa daf'u al-Mafāsid dan kaidah al-'Ādatu alMuhakkamatu. Korupsi yang bersifat memeras disikapi dengan kaidah al-Gharmu bi alGhanmi dan kaidah al-Muttafaqu 'alaihi Muqaddamun 'ala al-Mukhtalifi fìhi. Korupsi ontogenik disikapi dengan adanya kaidah al-Mașlaḥatu al-Ämmatu Muqaddamatun 'ala alMașlahati al-Khāsșati dan kaidah Lā Thawāba illā bi al-Niyyati. Korupsi defensif disikapi dengan kaidah al-Gharmu bi al-Ghanmi dan kaidah al-Yaqīnu lā yuzālu bi al-Shakki. Korupsi yang bersifat investasi disikapi dengan kehadiran kaidah al-Umūru bi maqāșidihā dan kaidah lā Darara wa là Dirāra. Korupsi berjenis nepotisme disikapi dengan adanya kaidah al-Darūrāt Tubīhu al-Makhdzūrāt dan kaidah al-Mașlaḥatu al-Ämmatu Muqaddamatun 'ala al-Maṣlahati al-Khāsșati. Korupsi suportif didewasakan dan disikapi dengan kehadiran kaidah al-Dararu Yudfa'u bi Qadri al-Imkān dan kaidah al-Mashaqqatu Tajlibu al-Taisīru.

Kasus tindak pidana korupsi dapat disikapi, diantisipasi, hingga diselesaikan dengan 5 hal. Pertama, penyelesaian sistem highly political cost. Kedua, penegasan dan pengetatan terhadap penegakan hukum. Ketiga, mengentaskan faktor ekonomi aparat pemerintah. Keempat, membijaki dan mengarifi budaya hedonisme dan konsumerisme. Kelima, pelestarian moral agama.

\section{Daftar Pustaka}

\section{Buku dan Hasil Penelitian;}

Alatas, S.H. Korupsi: Sifat, Sebab, dan Fungsi. Jakarta: Media Pratama, 1987.

Al-Qurtubi, Syams al-Dīn. al-Jāmi' li Ahkām Alquran. Beirut: Daar al-Fikr, T.Th, Juz ke-4.

Al-Shan'any, Muhammad bin Ismail. Subulus Salam. Beirut: Dar el-Fikr, 1990. 
Al-Sijistani, Sulaimān Ibn al-Asy'asy (Abū Dāwud), Sunan Abi Daawud, Juz ke-9, hadis nomor 2945.

Al-Ṭabarī, Abū Ja'far. Jāmi' al-Bayān fì Ta'wūl Alquran, Tahqīq/Ed. Ahmad Muhammad Syaakir. Juz ke-7. Bairut: Mu'assasat al-Risaalah, 2000.

Anwar, Syamsul. Fikih Anti Korupsi: Perspektif Ulama Muhammadiyah Majelis Tarjih dan Tajdid PP. Muhammadiyah. Jakarta: Pusat Studi Agama dan Peradaban, 2006.

Chazawi, Adami. Hukum Pidana Materiil dan Formiil Korupsi di Indonesia. Cet. II. Malang: Bayu Media, 2005.

Djamil, Fathurrahman. Metode Ijtihad Majlis Tarjih Muhammadiyah. Jakarta: Logos Wacana Ilmu, 1995.

Globethics.net International Secretariat, Etika dan Religiusitas Anti-Korupsi: Dari Konsep ke Praktek di Indonesia. Geneva: Globethics, 2015.

Haller Dieter, dan Shore, Cris. (Ed). Corruption: Anthropological Perspective. London: Pluto Press, 2005.

Hamzah, Andi. Pemberantasan Korupsi melalui Hukum Nasional dan Internasional, Cet. II. Jakarta: Raja Grafindo Persada, 2005.

Helmy, Masdar. Islam Profetik: Substansi Nilai-nilai Agama di Ruang Publik. Yogyakarta: Kanisius, 2008.

Katsir, Abu al-Fidaa' Ismail ibn 'Umar ibn. Tafsir Alquran al-'Azim, Tahqīq/Ed. Saami ibn Muhammad Salaamah. Riyad: Dār Tayyibah li al-Nașr waal-Tauz̄’’, 1999), Juz ke-2.

Kemitraan bagi Pembaruan Tata Pemerintahan. Survei Nasional Mengenai Korupsi di Indonesia. Jakarta: Tp. 2002.

Lubis, Todung Mulya. Peradilan Bebas dan Mandiri. Cetakan Pertama. Jakarta: Kompas, 2004.

Lopa, Baharuddin. Masalah Korupsi dan Pemecahannya. Cet. I. Jakarta: PT. Kipas Putih Aksara, 1997.

Poernomo, Soen'an Hadi. Berani Korupsi itu Memalukan: Bunga Rampai Filosofi, Masalah, Solusi Negeri Kelautan dan Upaya Pemberantasan Korupsi. Bandung: Imania, 2013.

Prinst, Darwan. Pemberantasan Tindak Pidana Korupsi. Bandung: Citra Aditya Bakti, 2002.

Quah, Jon S.T. Curbing Corruption in Asia: A Comparative Study of Six Countries. Singapore: Eastern University Press, 2003.

Rinaldi, Taufik. Purnomo, Marini. Damayanti, Dewi. Memerangi Korupsi di Indonesia yang Terdesentralisasi: Studi Kasus Penanganan Korupsi Pemerintah Daerah. Tp.: Justice for the Poor Project: Bank Dunia 2007.

Ricklefs, M.C. A History of Modern Indonesia since c. 1200, Edisi Ketiga. Great Britain: Palgrave Macmillan, 2001.

Tanthowi, Pramono. Membasmi Kanker Korupsi. Cetakan Pertama. Jakarta: Pusat Studi Agama dan Peradaban \& Partnership for Governance Reform in Indonesia, 2004.

\section{Jurnal;}

Dreher, Axel, dan Schneider, Friedrich. "Corruption and Shadow Economic an Empirical Analysis", Jurnal Springer. Vol. 144, No. 1 (Juli, 2010).

Hakim, Lukman. "Model Integrasi Pendidikan Anti Korupsi dalam Kurikulum Pendidikan Islam", Jurnal Pendidian Agama Islam-Talim, Vol. 10, No. 2, 2012.

Harrison, Elizabeth. "Corruption”, Development in Practice, Vol. 17, No. 4/5 (Agustus, 2007): 672-678.

Praklana, Mukhaer. “Otonomi Daerah di Persimpangan Jalan?” Equilibrium, Vol. 3, No. 1, 2005.

Rahim, Ruhimin Affandi Abdul. "Ijtihād dalam Institusi Fatwā di Malaysia: Satu Analisis." Jurnal Syariah, Vol. 17, No. 1, 2009. 
Shleifer, Andrei dan Vishny., Robert W. "Corruption”, Economics, Vol. 108, No. 3 (Agustus, 1993).

\section{Prosiding Seminar dan Makalah Perkuliahan;}

Sulaiman, Umar. "Korupsi dan Dialektika Manusia Sempurna: Sebuah Analisis Terhadap Peranan KPK dalam Pemberantasan Korupsi”Makalah disampaikan dalam Mata Kuliah Issues in Contemporary Dakwah, Sekolah Pascasarjana Universitas Islam Negeri Syarif Hidayatullah, Jakarta, 2016 dengan Dosen Pengampu: Prof. Andi Faisal Bakti, M.A., Ph.D.

\section{Disertasi/Tesis/Skripsi;}

Achmad, Nur. "Pencegahan Korupsi dalam Perspektif Hadis: Studi Hadis dalam Kutub alSittah." MA. Theses, Jakarta: Sekolah Pascasarjana Universitas Islam Negeri Syarif Hidayatullah, 2007.

Andrisman, Tri. "Pemberantasan Tindak Khusus Di Luar KUHP." MA. Thes, Bandar Lampung: Universitas Lampung, 2010.

Asmawi "Teori Mașlahăt dan Relevansinya dengan Perundang-Undangan Pidana Khusus di Indonesia.” Ph.D Diss. Jakarta: Sekolah Pascasarjana UIN Syarif Hidayatullah, 2009. 